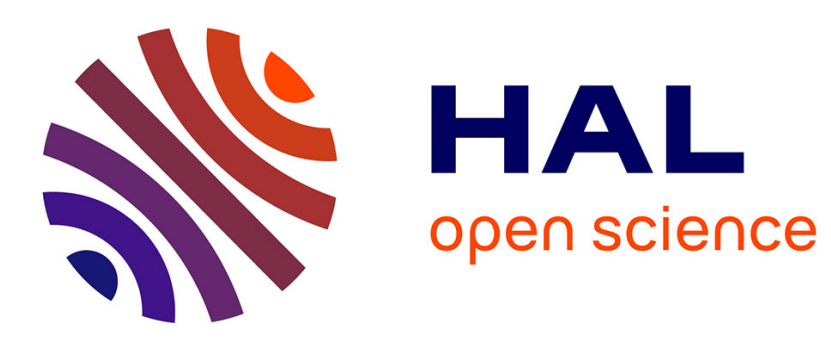

\title{
Cost estimation of heifer mastitis in early lactation by stochastic modelling
}

Kirsten Huijps, Sarne de Vliegher, Theo Lam, Henk Hogeveen

\section{To cite this version:}

Kirsten Huijps, Sarne de Vliegher, Theo Lam, Henk Hogeveen. Cost estimation of heifer mastitis in early lactation by stochastic modelling. Veterinary Microbiology, 2009, 134 (1-2), pp.121. 10.1016/j.vetmic.2008.09.018 . hal-00532482

\section{HAL Id: hal-00532482 \\ https://hal.science/hal-00532482}

Submitted on 4 Nov 2010

HAL is a multi-disciplinary open access archive for the deposit and dissemination of scientific research documents, whether they are published or not. The documents may come from teaching and research institutions in France or abroad, or from public or private research centers.
L'archive ouverte pluridisciplinaire HAL, est destinée au dépôt et à la diffusion de documents scientifiques de niveau recherche, publiés ou non, émanant des établissements d'enseignement et de recherche français ou étrangers, des laboratoires publics ou privés. 


\section{Accepted Manuscript}

Title: Cost estimation of heifer mastitis in early lactation by stochastic modelling

Authors: Kirsten Huijps, Sarne De Vliegher, Theo Lam, Henk Hogeveen

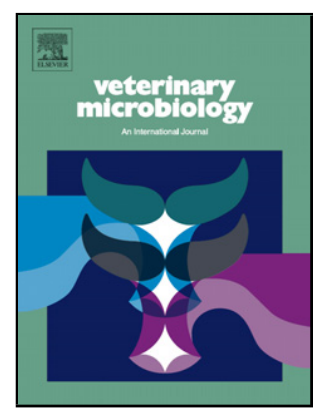

PII:

S0378-1135(08)00373-8

DOI: doi:10.1016/j.vetmic.2008.09.018

Reference: VETMIC 4158

To appear in:

VETMIC

Please cite this article as: Huijps, K., De Vliegher, S., Lam, T., Hogeveen, H., Cost estimation of heifer mastitis in early lactation by stochastic modelling, Veterinary Microbiology (2008), doi:10.1016/j.vetmic.2008.09.018

This is a PDF file of an unedited manuscript that has been accepted for publication. As a service to our customers we are providing this early version of the manuscript. The manuscript will undergo copyediting, typesetting, and review of the resulting proof before it is published in its final form. Please note that during the production process errors may be discovered which could affect the content, and all legal disclaimers that apply to the journal pertain. 


\section{Cost estimation of heifer mastitis in early lactation by stochastic modelling}

2

3 Kirsten Huijps $^{1^{*}}$, Sarne De Vliegher ${ }^{2}$, Theo Lam ${ }^{3}$, and Henk Hogeveen ${ }^{1,4}$

$4{ }^{1}$ Department of Farm Animal Health, Faculty Veterinary Medicine, Utrecht University,

5 Utrecht, the Netherlands

$6 \quad{ }^{2}$ Department of Reproduction, Obstetrics, and Herd Health, Faculty of Veterinary Medicine,

7 Ghent University, Merelbeke, Belgium

$8 \quad{ }^{3}$ Dutch Udder Health Centre, Deventer, the Netherlands

$9 \quad{ }^{4}$ Chair Group Business Economics, Wageningen University, the Netherlands

$11{ }^{*}$ Corresponding author:

12 Kirsten Huijps

13 Faculty Veterinary Medicine

14 Marburglaan 2

$153584 \mathrm{CN}$ Utrecht, the Netherlands

$16 \quad$ Tel: $+31-(0) 302532069$

$17 \quad$ Fax: $+31-(0) 302521887$

18 E-mail: k.huijps@uu.nl

19 


\section{Abstract}

Heifer mastitis, reflected by an elevated somatic cell count (SCC) in early lactation (SCCel), results in a decreased milk production, a higher risk for subclinical and clinical mastitis during lactation, and an elevated culling hazard. The aims of this study were to calculate the costs of heifer mastitis defined as an elevated SCC in early lactation, and to show the variation of these costs in the Dutch/Belgian dairy sector. A stochastic model, in which the variation and uncertainty of heifer mastitis are taken into account, was developed with input data from literature and expertise. Costs were estimated, using default values. The mean costs for an elevated SCCel that cured were on average $€ 13 /$ heifer present on a farm (range: $€ 0$ to $€ 118$ ), for an elevated $\mathrm{SCC}$ at calving proceeding in subclinical mastitis on average $€ 5 /$ heifer present on a farm (range: $€ 0$ to $€ 82$ ), and for a clinical heifer mastitis case associated with an elevated SCC after calving on average $€ 270$. On average this results in $€ 13 /$ heifer present on a farm (range: $€ 0$ to $€ 137$ ). Combined, these three cost aspects result in a total cost of on average $€ 31 /$ heifer present on a farm (range: $€ 0$ to $€ 220$ ). The large variation in the costs is very important regarding farm management and farm support. The difference in costs reflects also the difference in room for investment. When the costs that can be prevented are estimated at farm level, these data can be of help in setting goals in herd health advice and farm management.

Keywords: costs, economics, heifer, mastitis,

\section{Introduction}


Although mastitis during lactation seems to be less prevalent in heifers than in older cows, it is also in heifers a significant disease (Fox, 2007). In recent years heifer mastitis received more attention. It is identified (e.g. Barkema et al., 1998, De Vliegher et al., 2004) that a large proportion of heifers is infected at the moment of calving, incorporating a threat to production and udder health in the first and following lactations. During gestation impairment of mammary development can have potential detrimental effects on future milk production (De Vliegher, 2004, Rupp and Boichard, 2000). It has been shown that an elevated SCC in early lactation is associated with production losses (Coffey et al., 1986, De Vliegher et al., 2005a) and a higher risk for subclinical and clinical mastitis during lactation (Coffey et al., 1986, Rupp and Boichard, 2000, De Vliegher et al., 2004). Moreover, there is an increased hazard of culling which can partially be explained by the production losses and an increased risk for subclinical mastitis (De Vliegher et al., 2005b). Subclinical and clinical mastitis cases associated with an elevated SCC in early lactation will cause a decreased milk production and additional costs for veterinarian, drugs, culling, discarded milk and extra labour. Although the economics of mastitis has been covered in scientific literature (see for a recent overview Halasa et al., 2007), apart from prepartum treatment effects (Oliver et al., 2003) little attention has been paid to economical aspects of heifer mastitis. In the field of animal health economics, the main goal of economic calculations is to support decisions on health management. Management to specifically reduce the level of heifer mastitis should be focussed on reducing the level of infection before or during calving of heifers. When advising on management to reduce heifer mastitis, for most cases the starting point is the current farm situation (i.e. Oliver et al., 2003). A correct economic analysis is therefore a marginal analysis. Additional costs of improved management are compared with additional benefits (i.e., reduced costs of heifer mastitis) of that management. Calculations of the costs of heifer mastitis in the current situation, is the starting point for marginal economic analyses. 
Knowledge on the costs of heifer mastitis in the current situation determines the maximum room for investment in improved management. As such, it can support a decision whether or not to improve management.

The aim of this study were to calculate the costs of heifer mastitis defined as an elevated SCC in early lactation, both on farm and heifer level, and to show the variation of these costs in the Dutch/Belgian dairy sector. These cost calculations can be used as an indication of the room for investment in improved management on heifer mastitis.

\section{Materials and methods}

Based on calculation rules for mastitis described earlier (Huijps et al., 2007), a Monte Carlo simulation model has been developed using@Risk software (Palisade Corporation, Ithaca, NY, USA) to calculate the costs of heifer mastitis in a Dutch/Belgian situation. Monte Carlo simulation is a computer technique to simulate the reaction of a model under repeated measures. By taking different values from appropriate distributions of a parameter, the model becomes stochastic and thus can take the variation and risk into account. The model ultimately aims at supporting management decisions around heifer mastitis. We assume that this type of management should reduce the risk of infection before or during calving of heifers. In this study, heifer mastitis is therefore defined as heifers having an SCC higher than 200,000 cells/ml between 5 and 14 days in lactation (De Vliegher et al., 2004), referred to through this paper as SCC in early lactation (SCCel).

\subsection{Model description}


The model consists of 2 parts: the dynamics of heifer mastitis and the economic effects of heifer mastitis. First the model simulates the dynamics of heifer mastitis. Either the elevated SCCel cures or it remains elevated (De Vliegher et al., 2004). In the latter case proceeding into "subclinical mastitis in lactation". Alternatively, an elevated SCCel can be associated with a case of clinical mastitis during lactation (Rupp and Boichard, 2000). Secondly, the economic effects of heifer mastitis, using the outcome of the simulation of dynamics, were calculated. Economic effects are expressed as costs per average farm with 20 heifers and per average heifer present on the farm. Figure 1 shows a graphical representation of the model. Because of our definition there are relations (dashed arrows in Figure 1) that are not included in the model.

\section{Figure 1 near here}

All discrete events and variability at the cow level were triggered stochastically, using random numbers drawn from relevant distributions. Normal distributions were used when data were available and variables were normally distributed. When precise data were not available, minimum, most likely, and maximum values were put into a Pert distribution (Vose, 2000) to prevent overestimation of the extreme values. For parameters with a yes/no output (represented in the calculation as $1 / 0$ ) a discrete variable was used. By changing the variables that describe farm characteristics (number of heifers, number of heifers with elevated SCC, etc.) the variability of parameters can be controlled using these different distributions.

\section{Table 1 near here}


All input data were based on references, values in other papers, information provided by six bovine practitioners or on the authors' expertise. Input data for the dynamics of heifer mastitis, e.g. probabilities of getting mastitis, milk production losses, losses associated with discarding milk and culling are given in Table 1. Input data for the economic part, e.g. costs of production losses, veterinary costs, cost of treatment and drugs, labour costs, and culling costs are given in Table 2.

\section{Table 2 near here}

\subsection{Dynamics of heifer mastitis}

The model simulates the dynamics of heifer mastitis of individual heifers. For a default situation 20 heifers are simulated per farm. These heifers are simulated at the same time. It is assumed that a heifer (i) can have only one case of mastitis at a time. A number of consecutive simulation steps are taken per heifer. At first, each heifer is assigned with a milk production, which is normally distributed with an average milk production and an average standard deviation. Based on the assigned milk production, a relative milk production level is calculated, where 100 is the average milk production level of the farm. There are five groups of production levels made, group 1 with a low relative production level (75-90), group 2 with

140 a relative production level just below average (90-98), group 3 with a relative production

141 level around average (98-102), group 4 with a relative production level just above average

142 (102-110) and group 5 with a high relative production level (110-125). 

groups (group 1 is corresponding with a $\mathrm{SCCel}<200,000$ cells/ml, group 2 is corresponding with a SCCel between 200,000 and 500,000 cells/ml, group 3 is corresponding with a SCCel between 500,000 and 1,000,000 cells/ml and group 4 is corresponding with a SCCel $>1,000,000$ cells $/ \mathrm{ml}$ ). The probability of being in group $1,2,3$ or 4 is $35,25,22$ and $18 \%$, respectively (De Vliegher et al., 2004, experts).

Heifers with an elevated SCCel (SCCel group $=2,3$, or 4 ) can cure fast but also have a probability of developing subclinical mastitis during the first weeks of lactation as a result of this elevated SCCel. These cases of subclinical mastitis can be related with different SCC levels, $50 \%$ of the heifers are at the level of 50,000 cells $/ \mathrm{ml}, 25 \%$ at the level of 200,000 cells $/ \mathrm{ml}, 17.5 \%$ at the level of 500,000 cells $/ \mathrm{ml}, 5 \%$ at the level of $1,000,000$ cells $/ \mathrm{ml}$ and $2.5 \%$ at the level of 2,500,000 cells/ml (De Vliegher et al., 2004, experts).

An elevated SCCel is associated with an increased risk of clinical mastitis; subclinical mastitis can develop into clinical mastitis. A heifer can also get a clinical mastitis immediately after calving. The probability of getting clinical mastitis directly after calving has a Pert distributed value with a most likely value of $15 \%$, a minimum value of $10 \%$ and a maximum value of $20 \%$. The probability of getting clinical mastitis as a flare up of subclinical mastitis with a SCC of 50,000 cells $/ \mathrm{ml}, 200,000$ cells $/ \mathrm{ml}, 500,000$ cells $/ \mathrm{ml}, 1,000,000$ cells $/ \mathrm{ml}$ or 2,500,000 cells/ml are 5, 5, 5, 10 and 25\%, respectively (experts).

The production losses (expressed as a percentage loss of $\mathrm{kg}$ milk during the whole lactation) are dependent on the mastitis state. Production losses are respectively $1.1 \%, 1.8 \%$, $2.4 \%$ and $3.1 \%$ for SCCel group 1, 2, 3 or 4 . When a heifer has subclinical mastitis with a SCC of 50,000 cells $/ \mathrm{ml}, 200,000$ cells $/ \mathrm{ml}, 500,000$ cells $/ \mathrm{ml}, 1,000,000$ cells $/ \mathrm{ml}$ or 2,500,000 cells $/ \mathrm{ml}$ the production losses are $0,2,5,8$ and 10\%, respectively (De Vliegher et al., 2005b). For a clinical mastitis the production losses are $5 \%$. 
All clinical cases are treated by the farmer or the veterinarian. According to the practitioners in $5 \%$ of the clinical mastitis cases the veterinarian is consulted, the rest of the cases are treated by the farmer. The percentage of subclinical mastitis cases treated by the farmer is estimated at $5 \%$, the probability of consulting a veterinarian is estimated at $2 \%$. The treatment of clinical or subclinical mastitis is estimated to take 45 minutes per treated case.

When a heifer is treated there will be discarded milk for the period of treatment (estimated to be 4 days) and waiting days (estimated to be 5 days) (experts). production level. The probabilities of being culled for the different combinations of production level and mastitis status are given in Table 3.

Table 3 near here

\subsection{Economics}

Mastitis costs are caused by production losses, culling, visits of the veterinarian, drugs, discarded milk, and labour (Table 2). Costs of production losses are calculated by multiplying the amount of production losses $(\mathrm{kg})$ caused by an elevated SCCel, subclinical or clinical mastitis with the costs per $\mathrm{kg}$ of production losses. Costs of production losses within the Dutch quota system are estimated to be $€ 0.12$ per kg (Huijps et al., 2007). the costs for drugs. The total costs for discarded milk (DM) occur for the treated cases: 
where $\mathrm{Dm}_{\mathrm{i}}$ is the amount of discarded milk for heifer $\mathrm{i}$. the time spend on treatments with the hourly rate.

The costs for culling are dependent on the production level and are calculated by multiplying the number of cases culled with the culling costs per case. The culling costs per case are dependent on the production level of that heifer and can vary. The culling costs are estimated per relative production level defined as a Pert distribution with a minimum, most likely and maximum value (Table 3 ).

During the simulation many iterations are carried out. Each iteration consists of a calculation of all heifers of a farm, representing one year. Because of the distributions, outcomes per iteration (year) can vary. Outcomes were updated with results from each iteration until they reached a steady state, by monitoring the convergence of the outcomes. Monitoring convergence was done by calculating the percentiles ( 0 to $100 \%$ in $5 \%$ increments), mean, and standard deviation on the data generated for each output parameter at regular intervals throughout the simulation. These statistics were then compared with the same statistics calculated at the prior interval during the simulation. The amount of change in statistics due to the additional iterations was then calculated. When the convergence percentage reached $1.5 \%$, the outcome was regarded as having reached a steady state and the simulation was ended.

\subsection{Sensitivity analyses}

All input factors described above represent a default situation. All input factors can be changed by the user of the model to simulate different situations. In this research next to the 
default situation, a situation with more heifers and a situation with a higher probability of mastitis were carried out. To show the importance of the value of input factors a sensitivity analysis was carried out. All input variables were checked for values between $-10 \%$ and $+10 \%$ of the base value.

\section{Results and Discussion}

\subsection{Costs of heifer mastitis}

The purpose of economic calculations is to support decision making. Before considering changes in management on a certain disease, it is important to have insight in the room for investment for that particular disease. The total cost of a disease however, is not the same as the room for investment, which equals the preventable costs, given the constraints of a specific farm. Examples of such constraints are the farming system, the environment and the available housing. Given the constraints there exists some base level of mastitis that one should view as not preventable. When the total costs of a disease are known, determining the level of preventable and non-preventable costs, and thus the room for investment, requires expertise of the farmer and his advisor. Thus when considering taking measures against heifer mastitis, it is important to know what the costs of heifer mastitis on a specific farm are and which reliable goals can be set. Specific management around heifer mastitis is directed to the period before and during calving. The economic effects of heifer mastitis take place in primiparous cows. For primiparous cows having mastitis which does not originate from the period before or during calving, management is roughly the same as management for mastitis in multiparous cows. Therefore, in this study heifer mastitis was defined as primiparous cows having an elevated $(>200,000$ cells $/ \mathrm{ml})$ between 5 and 14 days after calving. The economic 
calculations were based on these cases of mastitis, and on subclinical and clinical mastitis cases potentially associated with it during lactation. This means that subclinical and clinical mastitis cases occurring during lactation in heifers with a normal SCCel $(<200,000$ cells $/ \mathrm{ml})$ are not included (these are the dotted lines in Figure 1). The use of a threshold of 200,000 cells/ml to define SCCel is debatable. Lower thresholds $(150,000$ cells $/ \mathrm{ml})$ are also used as threshold to define an increased level of SCC in primiparous cows. The somewhat higher threshold was used because the availability of effect estimations using this threshold (De Vliegher et al., 2004), which might have lead to a slight underestimation of the costs of heifer mastitis. Because of the lack of good transmission data, the costs of transmission of infections has also not been taken into account in the model. This might also have lead to an underestimation of the costs of heifer mastitis as presented in this paper.

Using default values, the total costs of heifer mastitis are $€ 626$ per farm level per year and $€ 31$ per heifer per year. These costs are distributed over an elevated SCCel after calving which cures (€260 and $€ 13)$, subclinical mastitis (€94 and €5) and clinical mastitis (€270 and $€ 13)$. The most important factors causing these costs are culling and production losses (Table 4). For all factors a large variation is present which is important to take into account. For instance, the total costs caused by heifer mastitis per average heifer present on a farm was only a small proportion of the total costs of mastitis per average cow on a farm, which was estimated to be $€ 140$ (Huijps et al., 2007). When comparing these costs, in addition to the definition being used in this study, the possibility of long term effects of heifer mastitis have to be taken into account. Rupp et al. (2000) showed that heifers with udder health problems during first lactation are more likely to have udder health problems in the second lactation as well, and Barker et al.(1998), showed that clinical mastitis during early lactation has a negative effect on the reproductive performance of the animals. The costs calculated in our study will therefore underestimate the real costs of mastitis in heifers. 
On farm level, the total costs of heifer mastitis for a farm with 20 heifers calving per year are on average $€ 626$ per year. However, the $5 \%$ percentile is $€ 85$ and the $95 \% € 1,657$. Some farmers may have many problems with heifer mastitis and for these farmers the costs will be much higher. A farm with 120 cows and 40 heifer calvings per year, will have higher total costs (on average $€ 1,220$ per year), but the variation is relatively smaller (€184- $€ 2,008$ per year) A farm with 65 cows (20 heifers) but with a very high risk of mastitis will have higher average costs $(€ 1,220)$ and a very large variation $(€ 314-€ 4,367$ per year). Figure 2 shows the total costs per average heifer present on a farm for these three different farm types (default, large farm and high risk farm). Important is that the average costs for the default and the large farm are more or less the same while the $5 \%$ and $95 \%$ interval is smaller for the larger farm due to the larger number of animals. For the farm with the high risk, the average costs as well as the $5 \%$ and $95 \%$ interval are higher.

In the costs mentioned above, the labour costs were included at $€ 18$ per hour. However, it is a difficult factor to quantify an hourly rate, and thus labour, in this type of calculations. On many (family) farms, opportunity costs of relatively small amounts of labour, such as in treatment of clinical mastitis cases, are zero. However, the work associated with mastitis is regarded as annoying (Kuiper et al., 2005). Therefore, in the default calculations, labour was included as a cost factor. When not including labour in the calculation, the total For implementation in other dairy systems or countries, the input variables should be adapted.

The costs calculated in this study apply to the Dutch/Belgian dairy sector including a quota system. Results of these calculations might therefore not be valid for other countries. 
Besides the total costs of a disease, it is important to know which part of these costs

can be prevented. If we know the amount of costs that can be prevented and the measures necessary to prevent them, this can be implemented in an advice and a change in farm management. Knowledge on the costs at herd level will support decisions how to prevent these costs. Regarding our default calculations, room for investments to improve the incidence of heifer mastitis is limited. But for farms with many problems there certainly is room for investment. Although dependent on the farm situation a theoretical base level for the room for investment for problem herds consists of a maximum of around $€ 900$ (the difference between the $90 \%$ and $10 \%$ farms).

\subsection{Sensitivity analysis}

Figure 3 shows the difference in total costs per year per average heifer present on a farm when varying the different input values with $+/-10 \%$ of the base value. Sensitivity analysis showed that the model is most sensitive for changes in the probability of calving with an elevated SCC, the probability of culling, culling costs, and production losses.

\section{Figure 3 near here}

In this paper we presented average costs and showed, with the sensitivity analysis, the importance of certain input factors. When using a cost calculation for a specific farm, it is important to adjust the calculations for that specific farm. The probability of calving with an elevated SCCel is an available parameter at farm level. The probability of culling, and culling costs are factors which are very uncertain and difficult to predict at farm level, but are very important in the model calculations. Historic data on culling are available but it is sometimes 
hard to judge the cause of culling. Another important factor is milk production. Heifers with an elevated SCC at calving that do not remain subclinically infected will have production losses (De Vliegher et al., 2005b). The production level of the farm is known, but production losses are difficult to see, because it is milk that is never produced and is therefore regarded as a hidden cost which is difficult to estimate. To develop stable and reliable model outcomes it is important to optimize the information of the factors which can be influenced on farm level and to estimate the other factors as good as possible by modelling, expertise, and available data. This can be further developed by using good farm management records.

\section{Conclusions}

Having knowledge on the costs of heifer, mastitis supports decision making. With a definition of heifer mastitis being primiparous cows having an elevated SCCel $(>200,000$ cells $/ \mathrm{ml}$ ) after calving, the average costs of heifer mastitis are under default circumstances $€ 626$ on farm level (€85 - €1657) and €31 (€4.29 - €82.86) per heifer present on a farm. The variation between the costs of farms is very large, which means that the room for investment in improved management on heifer mastitis differs between farms.

\section{Acknowledgement}

This study is part of the five years mastitis programme of the Dutch Udder Health Centre and was financially supported by the Dutch Dairy Board. The authors would like to thank the six bovine practitioners who gave input for the model.

\section{Conflict of interest}


None of the authors (K. Huijps, S. De Vliegher, T.J.G.M. Lam, H. Hogeveen) has a

345 financial or personal relationship with other people or organizations that could inappropriately

346 influence or bias the paper entitled "Cost estimation of heifer mastitis in early lactation by

347 stochastic modelling”.

\section{References}

Barkema, H.W., Schukken, Y.H., Lam, T.J.G.M., Beiboer, M.L., Wilmink, H., Benedictus, G., Brand, A., 1998. Incidence of clinical mastitis in dairy herds grouped in three categories by bulk milk somatic cell counts. J. Dairy Sci. 81, $411-419$.

Barker, A.R., Schrick, F.N., Lewis, M.J., Dowlen, H.H., Oliver, S.P., 1998. Influence of clinical mastitis during early lactation on reproductive performance of jersey cows. J. Dairy Sci. 81, 1285 - 1290.

Coffey, E.M., Vinson, W.E., Pearson, R.E., 1986. Somatic cell counts and infection rates for cows of varying somatic cell count in initial test of lactation. J. Dairy Sci. 69, $552-555$.

De Vliegher, S., 2004. Udder health in dairy heifers: some epidemiological and microbiological aspects. PhD thesis, UGent, Belgium.

De Vliegher, S., Barkema, H.W., Stryhn, H., Opsomer, G., de Kruif, A., 2004. Impact of early lactation somatic cell count in heifers on somatic cell counts over the first lactation. J. Dairy Sci. $87,3672-3682$.

De Vliegher, S., Barkema, H.W., Opsomer, G., de Kruif, A., Duchateau, L., 2005a. Association between somatic cell count in early lactation and culling of dairy heifers using Cox frailty models. J. Dairy Sci. 88, $560-568$. 
De Vliegher, S., Barkema, H.W., Stryhn, H., Opsomer, G., de Kruif, A., 2005b. Impact of early lactation somatic cell count in heifers on milk yield over the first lactation. J. Dairy Sci. $88,938-947$.

Fox, L.K., 2007. Prevalence and incidence of clinical and subclinical heifer mastitis. In: Proceedings Heifer mastitis conference 2007. Ghent, Belgium. pp. $62-64$.

Huijps, K., Lam, T.J.G.M., Hogeveen, H., 2007. Costs of mastitis: facts and perception. J. Dairy Res. 75, 113-120.

Kuiper, D., Jansen, J., Renes, R.J., Leeuwis, C., Van der Zwaag, H.G., 2005. Social factors related to mastitis and control practices: The role of dairy farmer's knowledge, attitude, values, behaviour, and networks. Mastitis in Dairy Production. Current knowledge and future solutions. $4^{\text {th }}$ IDF International Mastitis Conference Maastricht. Pp. $567-582$. The Netherlands: Wageningen Academic Publishers.

Oliver, S.P., Lewis, M.J., Gillespie, B.E., Dowlen, H.H., Jaenicke, E.C., Roberts, R.K., 2003. Prepartum antibiotic treatment of heifers: milk production, milk quality and economic benefit. J. Dairy Sci. 86, $1187-1193$.

Rupp, R., Boichard, D., 2000. Relationship of early first lactation somatic cell count with risk of subsequent first clinical mastitis. Liv. Prod. Sci. 62, $169-180$.

Van den Borne, B.H.P., Van Schaik, G., Nielen, M., Lam, T.J.G.M., 2007. Prevalence and incidence of (sub)clinical mastitis in heifers in a random sample of dairy herds in the Netherlands. In: Proceedings Heifer Mastitis Conference 2007, Ghent, Belgium. Pp. 65 $-66$.

Van der Walle, K., 2004. Gebruikswaarde van melkvee. Internal report. Animal Science Group Wageningen UR, Lelystad, the Netherlands.

Vose, D., 2000. Defining distributions from expert opinions. In: Risk Analysis: A quantitative guide. $2^{\text {nd }}$ ed. John Wiley \& Sons. Chichester, UK. Pp. $262-271$. 
392 Input data of the stochastic simulation model for the dynamics of heifer mastitis for an

393 elevated somatic cell count in early lactation (between 5 and 14 days in milk) (SCCel) which

394 cures, an elevated SCCel proceeding into subclinical mastitis (Sub.), and an elevated SCCel

395 associated with clinical mastitis (Clin.).

\begin{tabular}{|c|c|c|c|c|}
\hline & SCCel & Sub. & Clin. & Reference \\
\hline Probability of & & 0.10 & 0.10 & De Vliegher et al., 2004 \\
\hline Most likely & 0.35 & 0.15 & 0.15 & Van den Borne et al., 2007 \\
\hline Maximum & & 0.2 & & \\
\hline Production losses & $0-3.1 \%^{1}$ & $0-10 \%{ }^{1}$ & . & $\begin{array}{l}\text { De Vliegher et al., 2005b } \\
\text { Hortet and Seegers, } 1998\end{array}$ \\
\hline $\begin{array}{l}\text { Probability } \\
\text { treatment vet }\end{array}$ & 0 & & $5 \%$ & Bovine practitioners \\
\hline $\begin{array}{l}\text { Probability } \\
\text { treatment farmer }\end{array}$ & 0 & $5 \%$ & All & Bovine practitioners \\
\hline Withholding period & 9 & 9 & 9 & Bovine practitioners \\
\hline - Treatment days & 4 & 4 & 4 & Bovine practitioners \\
\hline - Waiting days & 5 & 5 & 5 & Bovine practitioners \\
\hline Labor time farmer (minutes) & 45 & 45 & 45 & Bovine practitioners \\
\hline Probability culling & $1-10 \%^{2}$ & $8-13 \%^{2}$ & $8-13 \%^{2}$ & De Vliegher et al., 2005a \\
\hline
\end{tabular}

${ }^{1}$ The production losses depend on the individual SCC of the heifer

$397{ }^{2}$ The probability of culling is depends on the production level of the heifer 
Table 2

399 Input data of the stochastic simulation model for the general and economic input of heifer 400 mastitis for an elevated somatic cell count in early lactation (between 5 and 14 days in milk)

401 (SCCel) which cures, an elevated SCCel proceeding into subclinical mastitis, and an elevated 402 SCCel associated with clinical mastitis.

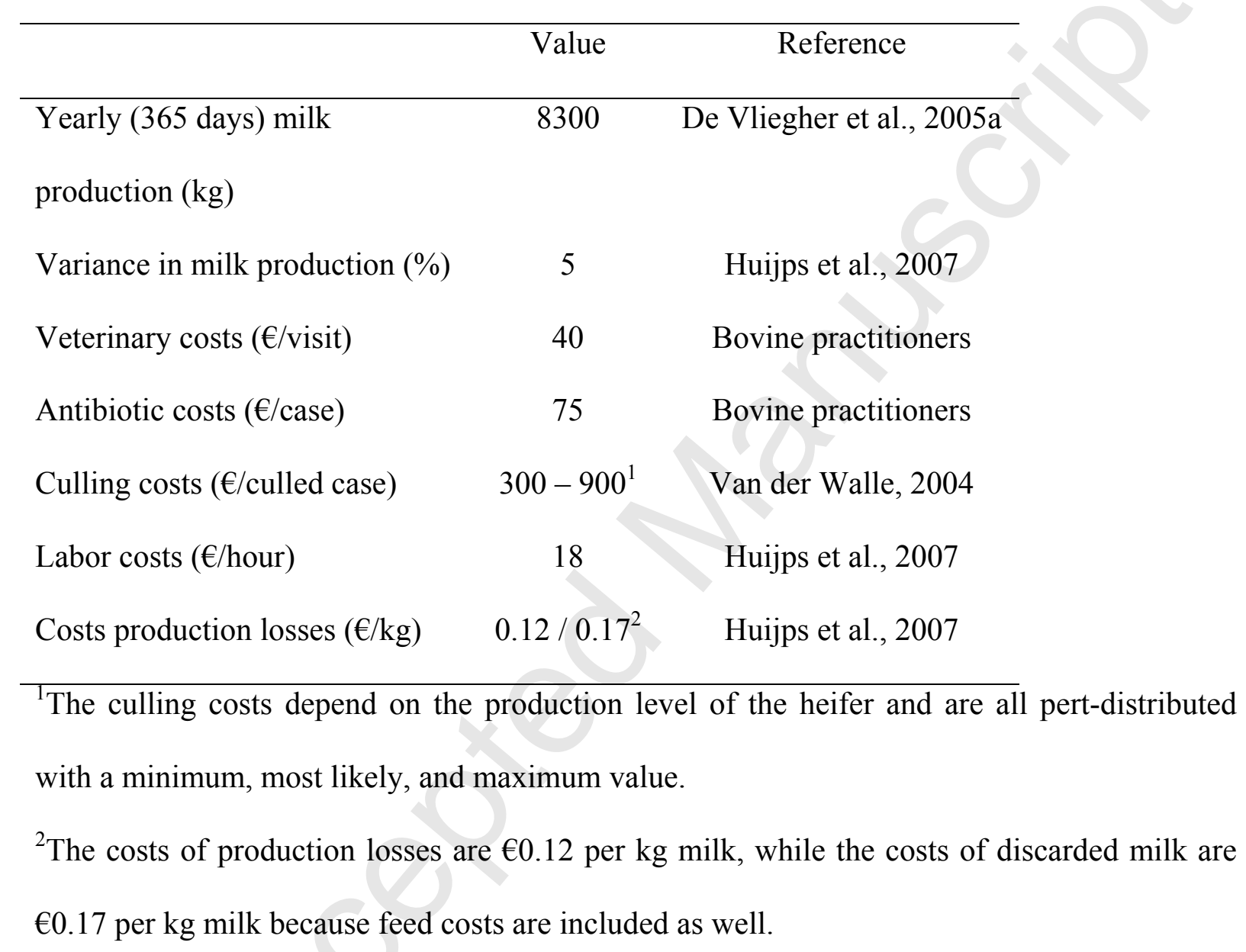


Table 3

408 Probabilities of being culled and culling costs (minimum, most likely, maximum) for the

409 different combinations of production level and elevated somatic cell count in early lactation

410 (SCCel), subclinical or clinical mastitis, based on De Vliegher et al., 2004 and expert opinion,

411 as used in the stochastic model.

\begin{tabular}{cccccc}
\hline Production level & SCCel & $\begin{array}{c}\text { Subclinical or clinical } \\
\text { mastitis }\end{array}$ & \multicolumn{2}{c}{ Culling costs $(€ /$ culled case) } \\
& & & & \\
& & & & \\
minimum & most likely & maximum \\
\hline 1 & $10 \%$ & $13 \%$ & 300 & 400 & 500 \\
3 & $7 \%$ & $12 \%$ & 400 & 500 & 600 \\
4 & $5 \%$ & $11 \%$ & 500 & 600 & 700 \\
5 & $3 \%$ & $8 \%$ & 600 & 700 & 800 \\
\hline
\end{tabular}

412

413 
Table 4

414 Costs for an elevated somatic cell count in early lactation (SCCel) which cures, and for

415 subclinical and clinical mastitis associated with an elevated SCCel. Given are the averages

416 (minimum and maximum) in € per average heifer present.

\begin{tabular}{|c|c|c|c|c|c|c|}
\hline \multirow[t]{2}{*}{ Cost Factor } & \multicolumn{2}{|c|}{ SCCel } & \multicolumn{2}{|c|}{ Subclinical } & \multicolumn{2}{|c|}{ Clinical } \\
\hline & Farm & Heifer & Farm & Heifer & Farm & Heifer \\
\hline Production & 112.38 & 5.61 & 17.12 & 0.86 & 59.31 & 2.94 \\
\hline losses & $(0-291.66)$ & $(0-14.58)$ & $(0-258.05)$ & $(0-12.90)$ & $(0-432.60)$ & $(0-18.46)$ \\
\hline Discarded & - & - & 2.70 & 0.14 & 39.36 & 1.95 \\
\hline milk & & & $(0-82.55)$ & $(0-4.12)$ & $(0-287.12)$ & $(0-12.25)$ \\
\hline \multirow[t]{2}{*}{ Veterinarian } & - & - & 0.96 & 0.05 & 1.88 & 0.11 \\
\hline & & & $(0-80)$ & $(0-4)$ & $(0-80)$ & $(0-5.33)$ \\
\hline \multirow[t]{2}{*}{ Drugs } & - & - & 5.55 & 0.28 & 83.82 & 4.15 \\
\hline & & & $(0-150)$ & $(0-7.5)$ & $(0-600)$ & $(0-25)$ \\
\hline \multirow[t]{2}{*}{ Culling } & 150.31 & 7.51 & 67.37 & 3.37 & 70.95 & 3.49 \\
\hline & $(0-2257.85)$ & $(0-112.89)$ & $(0-1590.12)$ & $(0-79.51)$ & $(0-2064.14)$ & $(0-104.29)$ \\
\hline \multirow[t]{2}{*}{ Labour } & & & 0.67 & 0.03 & 14.45 & 0.71 \\
\hline & & & $(0-27)$ & $(0-1.35)$ & $(0-108)$ & $(0-4.5)$ \\
\hline \multirow[t]{2}{*}{ Total } & 262.70 & 13.13 & 94.37 & 4.72 & 269.78 & 13.49 \\
\hline & $(0-2375.52)$ & $(0-118.78)$ & $(0-1637.48)$ & $(0-81.83)$ & $(0-2756.19)$ & $(0-137.81)$ \\
\hline
\end{tabular}

417 
417 Fig. 1. Graphical representation from one heifer of the stochastic model to simulate the

418 dynamics of heifer mastitis and its economic consequences. The dashed arrows are relations

419 that are not included in the calculation.

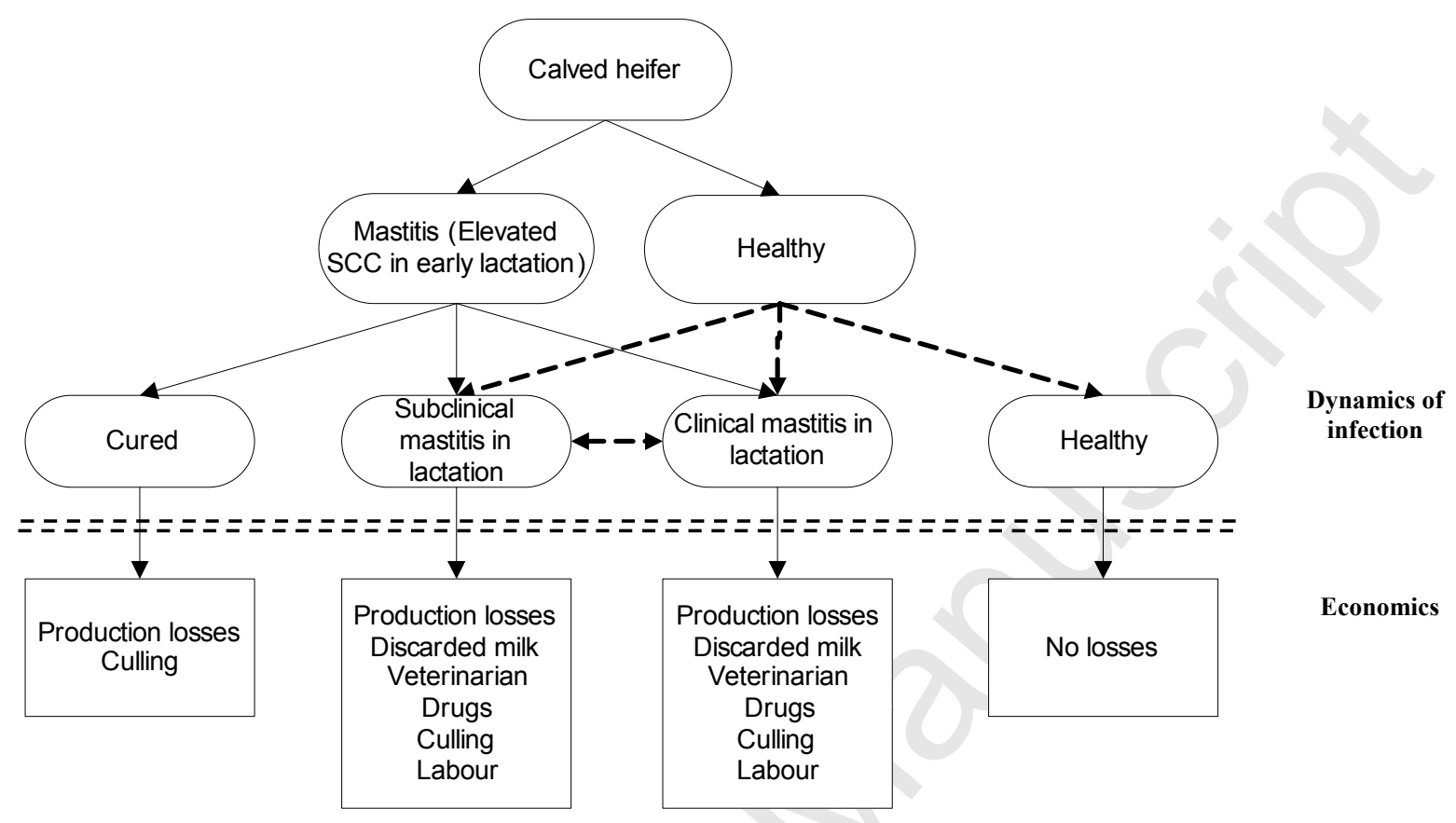


421 Fig. 2. Farm level costs for three different types of farms: average farm with 65 cows and 20

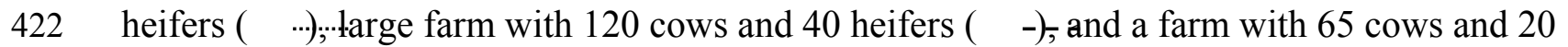

423 heifers with a high risk of mastitis ( $)$

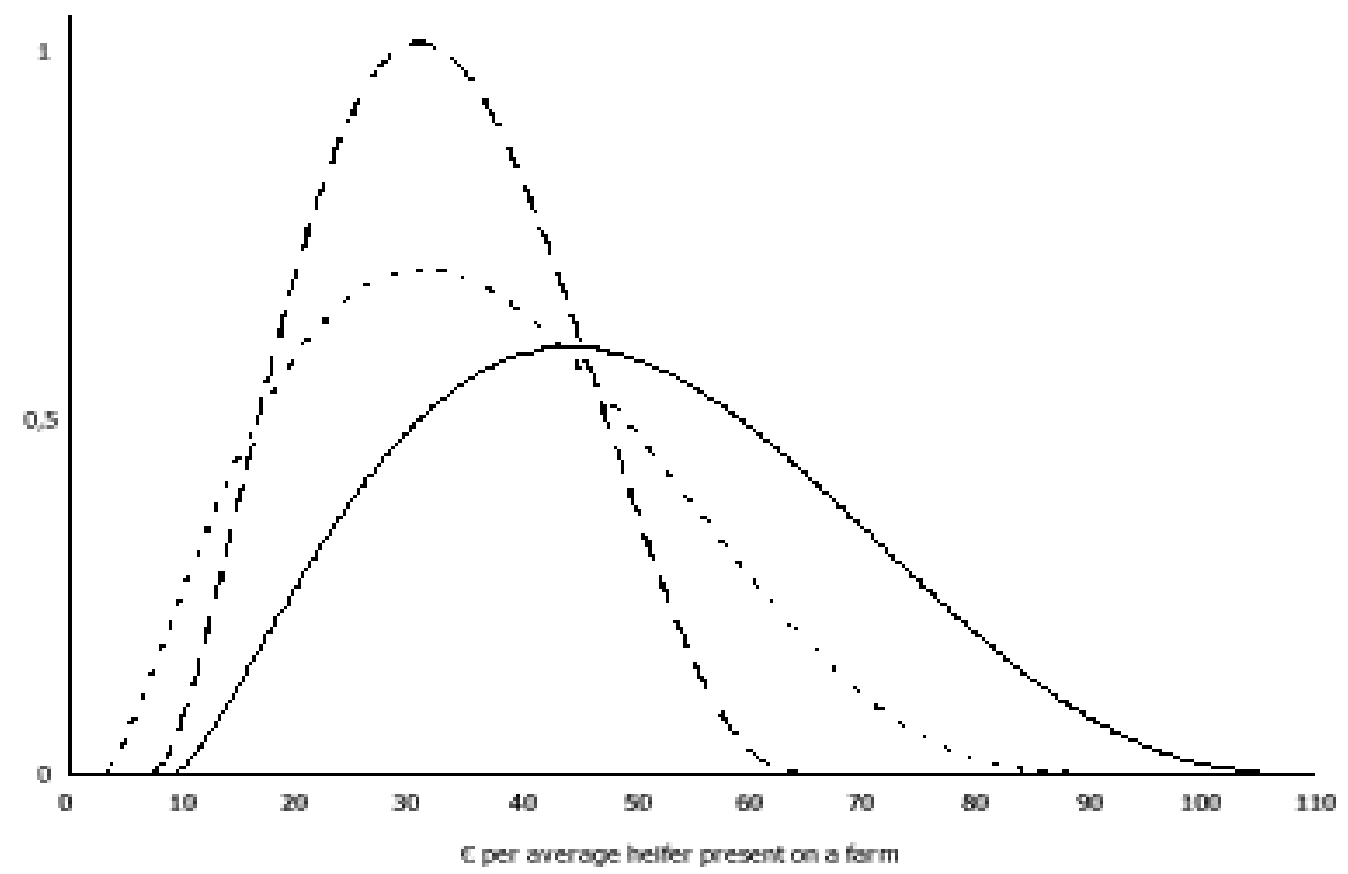

424 
425 Fig. 3. Results in $€$ per average heifer present on a farm of the sensitivity analysis for different

426 input values with $+/-10 \%$ deviation from the default value.

427

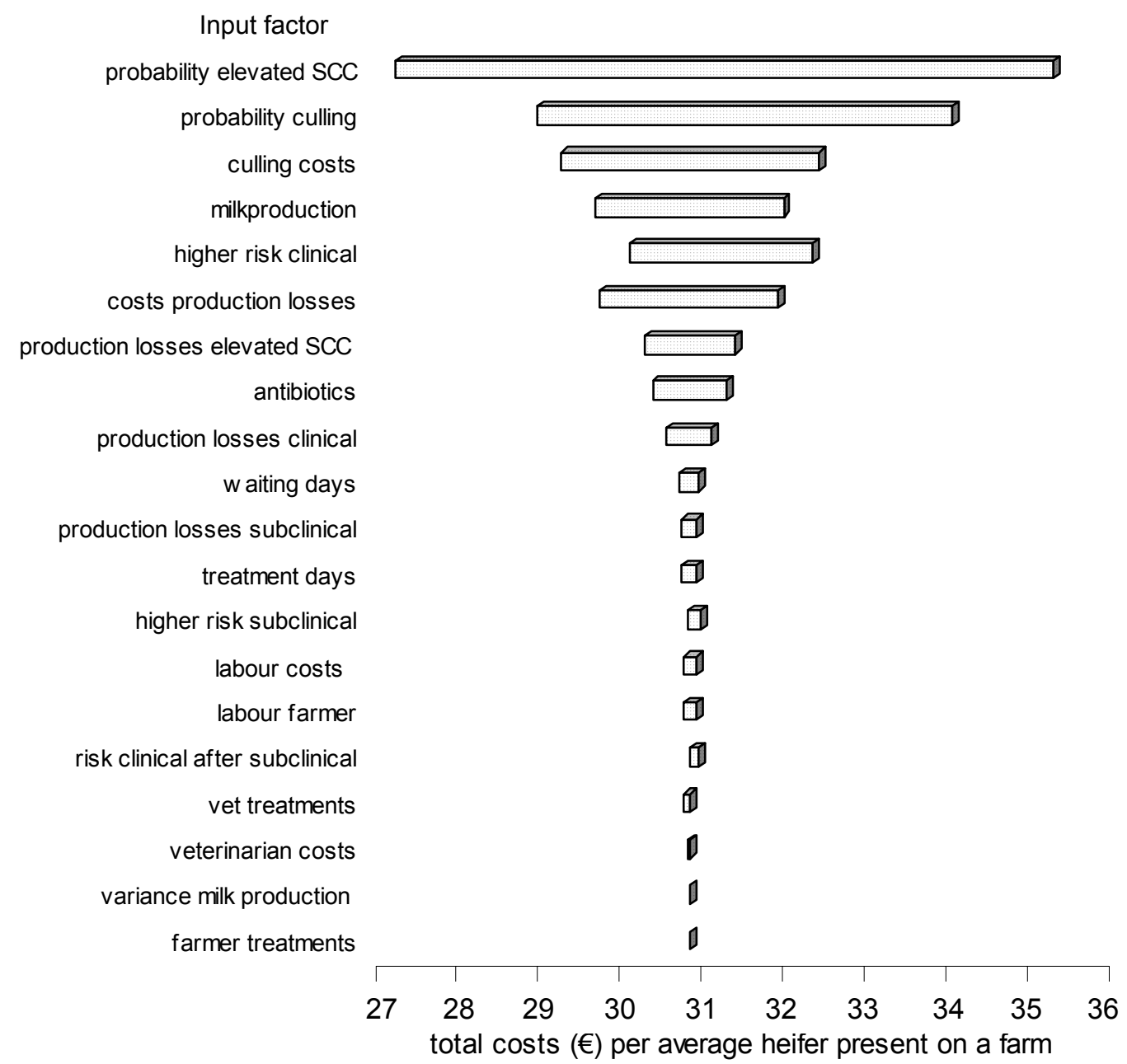

